\title{
On-Membrane Digestion Technology for Muscle Proteomics
}

\author{
Kay Ohlendieck
}

\author{
Department of Biology, National University of Ireland, Maynooth, Co. Kildare, Ireland
}

\begin{abstract}
High-resolution two-dimensional gel electrophoresis and in-gel digestion are routinely used for large-scale protein separation and peptide generation in mass spectrometry-based proteomics, respectively. However, the combination of isoelectric focusing in the first dimension and polyacrylamide slab gel electrophoresis in the second dimension is not suitable for the proper separation of integral proteins and high-molecular-mass proteins. In addition, ingel trypsination may not result in a high degree of efficient digestion levels for the production of large numbers of peptides in the case of certain protein species. The application of gradient one-dimensional gel electrophoresis and onmembrane digestion can overcome these technical problems and be extremely helpful for the comprehensive identification of proteins that are underrepresented in routine two-dimensional gel electrophoretic approaches. This review critically examines the general application of on-membrane digestion techniques in proteomics and its recent application for the identification of very large integral membrane proteins from skeletal muscle by mass spectrometry. This includes the discussion of proteomic studies that have focused on the proteomic characterization of the membrane cytoskeletal protein dystrophin from sarcolemma vesicles and the ryanodine receptor calcium release channel of the sarcoplasmic reticulum from skeletal muscle.
\end{abstract}

Keywords: Dystrophin, on-membrane digestion, mass spectrometry, muscle proteomics, ryanodine receptor.

\section{INTRODUCTION}

The usage of adsorbent membranes as support material for blotted biomolecules is widely used in analytical biochemistry [1]. The electrophoretic transfer of DNA, RNA and protein is routinely achieved by Southern, Northern and Western blotting techniques, respectively [2-4]. Blotting techniques are highly sensitive and specific for the identification of unique nucleic acid sequences or protein epitopes. Hence, the efficient transfer of DNA, RNA or protein from a gel system onto a membrane support is critical in these frequently used techniques $[5,6]$. The electrophoretic transfer of proteins to membrane sheets was originally described by Towbin and co-workers in 1979 [7] and has been extensively applied in basic and applied bioresearch over the last few decades [8-10]. Protein blotting technology is now a key analytical approach in the biochemical identification and characterization of peptides, protein subunits, protein isoforms and protein complexes, as well as post-translational modifications. Western blotting analysis has been continuously modified and improved for novel applications in protein biochemistry [11]. Extensively modified protein blotting methods are represented by Southwestern blotting for investigating DNA-protein interactions [12-14] and FarWestern blotting for the detection of protein-protein interactions [15-17]. Blot overlay methods combine the gel electrophoretic separation of proteins, blotting to a membrane and then incubation with a labeled probe

\footnotetext{
*Address correspondence to this author at the Department of Biology, National University of Ireland, Maynooth, Co. Kildare, Ireland; Tel: (353) (1) 708-3842; Fax: (353) (1) 708-3845; E-mail: kay.ohlendieck@nuim.ie
}

other than an antibody, such as a fluorescently labeled or enzyme-conjugated protein of interest [18-20].

Protein transfer technology has also been integrated into modern mass spectrometry-based proteomics [21], especially exploiting the efficient onmembrane proteolytic digestion of electro-blotted molecules for swift protein identification [22]. Proteomics is a technology-driven and hypothesisgenerating approach that combines established biochemical and protein chemical methods for the comprehensive survey of large protein populations [2325]. Modern proteomics is of crucial importance for the large-scale identification of proteins in diverse fields such as basic cell biology [26], preclinical drug discovery [27] and systems biology [28]. Thousands of proteins from crude tissue extracts can be separated by high-throughput liquid chromatography [29] or gel electrophoresis [30] covering a large portion of the whole tissue proteome. However, if certain classes of proteins from a dynamic cellular system cannot be sufficiently enriched by standard biochemical approaches, organelle proteomics can be employed to reduce sample complexity with the help of sophisticated pre-fractionation steps prior to proteomic analysis [31-33]. In-gel trypsination is the most frequently used method to generate peptides from gel electrophoretically separated protein mixtures [34, 35]. However, this technique does sometimes not result in an efficient proteolysis of distinct protein species for their subsequent identification by mass spectrometry, which necessitates the application of alternative methods such as on-membrane trypsination [21, 22]. Since membrane-bound proteins appear to be more 
prominently exposed to proteases, the controlled digestion of proteins transferred from gel bands or spots to membrane sheets is advantageous when studying certain protein species. This is especially relevant for proteins with unusual properties with respect to charge, hydrophobicity, size and/or density. This review outlines recent applications of onmembrane digestion techniques in muscle proteomics and critically examines its application for the characterization of high-molecular-mass membrane proteins by mass spectrometry.

\section{GEL ELECTROPHORETIC PROTEIN SEPARA- TION}

The efficient separation of proteins from complex tissues, the unequivocal identification of individual protein species within heterogeneous protein mixtures, the determination of protein abundance and isoform expression patterns in dynamic cellular systems, and the comprehensive characterization of posttranslational modifications are at the core of analytical protein biochemistry. For the cataloguing of entire protein populations, the comparative analysis of differing proteomes or the identification of novel protein biomarkers, the proteomic workflow involves at least five critical steps, i.e. (i) sample preparation from defined body liquids, crude tissue extracts or subcellular fractions, (ii) protein separation via liquid chromatography and/or gel electrophoresis, (iii) computer-assisted analysis of proteomic maps, (iv) efficient protein digestion for the generation of meaningful peptide signatures, and $(v)$ the unequivocal identification of individual protein species by highly sensitive mass spectrometry [25]. Since this review focuses on the mass spectrometric identification of very large proteins following gel electrophoretic separation, this section briefly lists the most frequently employed methods that are based on gel matrixes for protein analysis.

Proteins are routinely separated by size and/or charge in one-dimensional or two-dimensional gels depending on the specific method of choice. Onedimensional gel electrophoretic methods used in protein biochemistry include isoelectric focusing and sodium dodecyl sulfate polyacrylamide gel electrophoresis [36], as well as non-denaturing gel electrophoresis, such as Native Blue gel electrophoresis [37]. For large-scale applications, preparative gel systems are available including the Rotofor system and the Prep Cell instrument [38]. These preparative protein separation devices are based on a multi-chamber system using carrier ampholyte focusing or a cylindrical compartment for continuous-elution gel electrophoresis [39, 40]. An interesting alternative to conventional gel electrophoresis is offgel electrophoresis, which is a free-flow protein method based on isoelectric focusing in solution [41-43]. Offgel electrophoretic prefractionation of crude tissue homogenates has recently been successfully applied to the subproteomic analysis of basic proteins in aged skeletal muscle [44].

Two-dimensional gel electrophoresis has been extensively used in biochemical research [45] and is one of the most frequently employed separation techniques in large-scale proteomic surveys due to its enormous capacity and high resolution [46-48]. The most commonly used method combines isoelectric focusing in the first dimension and polyacrylamide slab gel electrophoresis in the second dimension [49]. Alternative approaches use native gel electrophoresis in the first dimension [50] or separate protein complexes by diagonal reducing/non-reducing twodimensional gel electrophoresis [51]. Two-dimensional gel electrophoresis has been continuously advanced for improved separation and characterization of proteins [52], especially with respect to large highresolution gel systems for the separation of entire proteomes [53]. Hundreds to thousands of individual protein spots can be visualized depending on protein loading conditions and staining methodology [54-56]. Standard staining approaches include Coomassie Brilliant Blue [54] and silver [57, 58], as well as a variety of fluorescent dyes [58-61]. One of the most powerful comparative ways of analyzing proteomes is fluorescence difference in-gel electrophoresis [62], which uses 2-CyDye or 3-CyDye systems to differentially label proteins belonging to dissimilar protein mixtures prior to gel electrophoretic separation [63-65]. Two-dimensional difference in-gel electrophoresis incorporating a pooled internal standard, originally described by Alban et al. [66], can routinely analyse over 2,000 proteins using triple fluorescent labeling [67-69]. However, although highresolution two-dimensional gel electrophoresis is an excellent separation tool for studying urea-soluble proteins, this method usually under-represents certain classes of proteins, such as low copy number proteins, very large proteins, membrane-associated proteins and proteins with extreme isoelectric points [70]. Thus, comprehensive proteomic studies of complex tissues often require additional separation steps to fully cover the membrane and organelle proteome [71-73]. 


\section{PROTEIN DIGESTION FOR PROTEOMIC ANALYSIS}

Gel electrophoresis and transfer blotting have long been used as preparative tools to isolate and/or immobilize individual proteins for subsequent microsequence analysis [74-76]. It is relatively simple to prepare proteins for automated Edman microsequencing following gel electrophoresis [77] or blotting [78]. In the case of gel-embedded proteins, their efficient elution from the gel matrix, the removal of excess detergent and renaturing of the target protein are crucial steps prior to biochemical analysis [79]. Micro-sequencing of immobilized proteins following blotting has been used for direct tryptic digestion on nitrocellulose replicas [80] or $\mathrm{N}$-terminal sequencing on polyvinylidine difluoride membranes [81, 82]. For proteomic studies, relatively high yields of tryptic peptides could be extracted from $1 \mathrm{~mm}$ thick gel bands at $200 \mathrm{fmol}$ to $10 \mathrm{pmol}$ levels [83], whereby this in-gel digestion method is suitable for automated applications [84]. Both, in-gel trypsination and on-membrane digestion at sub-pmol protein quantities are able to produce a sufficient number and size of released peptides for the successful identification of standard proteins ranging from $17 \mathrm{kDa}$ to $97 \mathrm{kDa}$ by matrixassisted laser-desorption/ionization mass spectrometry [85].

Although in-gel digestion is a widely used and highly suitable method for the preparation of peptides from the majority of proteins [83-85], the trypsination of certain target proteins may not be efficient enough for routine mass spectrometric analysis and might thus require alternative approaches [86-88]. Importantly, the on-membrane digestion method is faster as compared to conventional in-gel trypsination [89-91], which can considerably reduce technical complications due to trypsin autolysis [92]. In general, the usage of MS grade trypsin, accelerated digestion protocols, suitable solvent systems and specific protease combinations can considerably reduce the appearance of autolytic trypsin fragments in proteomic analyses [93-95]. Onmembrane digestion has been reported to result in superior protein sequence coverage as compared to ingel methods [96], which makes this biochemical technique especially suitable for the proteomic identification of low-abundance proteins, hydrophobic proteins and high-molecular-mass proteins [97, 98]. Interesting applications of the on-membrane method has been the analysis of glycoproteins [99-101], phosphoproteins [102-104] and DNA-binding transcription factors [105-107].
Following protein digestion, highly sensitive mass spectrometric approaches are used for the highthroughput identification of proteins [108]. Several excellent reviews have summarized the importance of mass spectrometry for modern protein analysis [109111] and its extended usage in large-scale proteomic investigations [112-114]. A key step in proteomics is successful protein digestion and generation of large and representative numbers of peptides. Figure 1 summarizes the main features of in-gel digestion following two-dimensional gel electrophoresis of total extracts versus on-membrane digestion following onedimensional gel electrophoresis and blotting of subcellular fractions. Ideally, both techniques are used in combination to achieve the near-to-complete coverage of a given tissue proteome. The onmembrane digestion technique has recently been applied to the identification of extremely large proteins from skeletal muscle tissue [97, 98]. Muscle proteomics is concerned with the large-scale biochemical analysis of fibre-associated proteins and attempts to catalogue all components of the muscle proteome and determine protein changes in developing, adapting, transforming, pathological and aging contractile tissues [115-117]. The two investigated high-molecular-mass proteins exist under physiological conditions as supramolecular membrane assemblies in skeletal muscle fibres, i.e. the membrane cytoskeletal protein dystrophin in a glycoprotein-associated complex in the sarcolemma [118] and the ryanodine receptor $\mathrm{Ca}^{2+}$-release channel in a tetrameric structure at the triad junction between transverse tubules and the sarcoplasmic reticulum [119]. On-membrane digestion was instrumental in the proteomic characterization of these two high-molecularmass skeletal muscle proteins.

\section{PROTEOMIC IDENTIFICATION OF DYSTROPHIN BY ON-MEMBRANE DIGESTION}

Individual members of the super family of large actin-binding proteins, consisting of spectrins, dystrophins and utrophins, have originated from a common ancestral $\alpha$-actinin molecule and exist in many different isoforms with a wide tissue distribution throughout the body [120]. The full-length dystrophin isoform Dp427, which absence triggers progressive muscle wasting in Duchenne muscular dystrophy [121], forms tight interactions with integral glycoproteins in the plasmalemma [122]. Dystrophin of $427 \mathrm{kDa}$ constitutes approximately $5 \%$ of the actin-associated membrane cytoskeleton in the subsarcolemmal region of skeletal muscle [123]. In healthy muscle tissue, dystrophin binds to $\beta$-dystroglycan that in turn interacts with 


\section{A 2D Gel Electrophoresis and In-Gel Digestion}

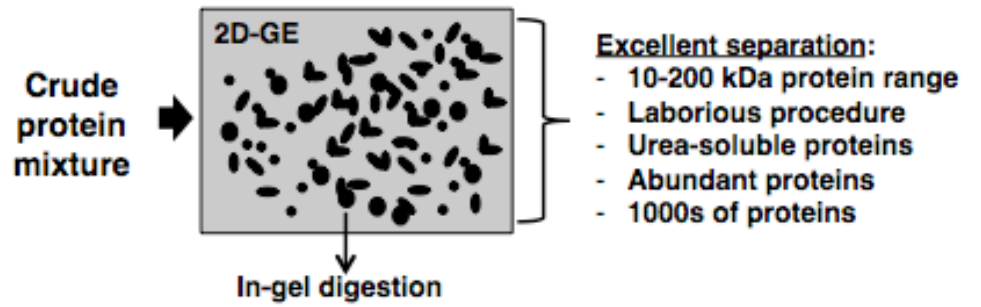

Under-representation of:

- Integral proteins

- Low-abundance proteins

- High molecular mass proteins

- Very basic or acidic proteins

- Proteins with extensive PTMs

\section{B 1D Gradient Gel Electrophoresis and On-membrane Digestion}

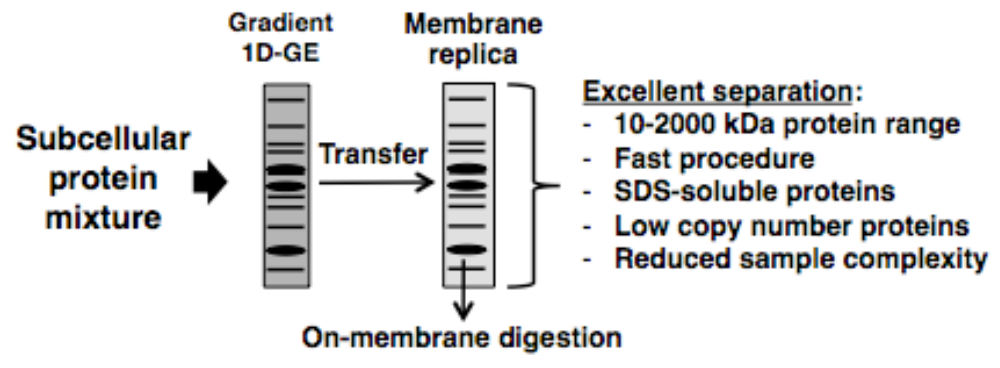

Improved presentation of:

- High molecular mass proteins

- Integral proteins

- Low-abundance proteins

- Proteins with extreme $\mathrm{p} /$-values

- Proteins with extensive PTMs

Figure 1: Comparison of major analytical features of two-dimensional gel electrophoresis and in-gel protein digestion versus one-dimensional gradient gel electrophoresis and on-membrane protein digestion. Shown are diagrams of 2D gel-based in-gel digestion (A) and 1D gel-based on-membrane digestion (B) and lists of advantages and potential disadvantages of these two methods when used as large-scale separation techniques in proteomic profiling studies.

extracellular $\alpha$-dystroglycan, a receptor for laminin. This membrane assembly provides a transsarcolemmal linkage between the intracellular actin cytoskeleton and the extracellular matrix of the basal lamina and thereby stabilizes the muscle periphery during excitation-contraction-relaxation cycles [118]. Loss of dystrophin results in the disintegration of the membrane complex and causes a severe reduction in all dystrophin-associated glycoproteins [124-126].

A large number of gel-based proteomic studies have compared the expression profile of normal versus dystrophic muscle tissue [127], but have disappointingly not identified dystrophin and its associated glycoproteins by standard two-dimensional gel electrophoresis and in-gel digestion approaches [128-130]. This is probably due to the large size of dystrophin and the relative low levels of the constituents of the dystrophin-glycoprotein complex in crude tissue extracts. However, alternative approaches have successfully identified components of this surface complex by mass spectrometry. Figure 2 outlines the various analytical steps involved in the proteomic characterization of the muscle plasma membrane. The experimental conditions and main solutions employed in on-membrane digestion of gel electrophoretically separated proteins are shown in Figure 3. The flowchart lists the composition of the electrophoretic transfer buffer used in the transblotting from gels to membrane sheets, as well as the trypsin stock solution and extraction buffer that are routinely employed for the proteolytic generation of peptides for the subsequent mass spectrometric identification of proteins of interest.

On-membrane digestion of dystrophin and its associated glycoproteins was carried out with both isolated sarcolemma vesicles and the highly purified dystrophin complex [97]. For studying sarcolemma vesicles, individual fractions from microsomal membranes were separated by density gradient centrifugation and then lectin agglutination was used to affinity purify surface membrane vesicles [122, 123, 131]. Right-side-out sarcolemma vesicles expose a large number of carbohydrate moities that can directly interact with a suitable lectin, such as wheat germ agglutinin [122]. Contaminating material, such as trapped smaller vesicles or adsorbed proteins, can be conveniently removed by mild detergent washing steps [123]. Lectins are finally removed from the agglutinated vesicle fraction by incubation with a competitive sugar, such as $\mathrm{N}$-acetylglucoseamine in the case of wheat germ agglutinin [131]. Mass spectrometry clearly 


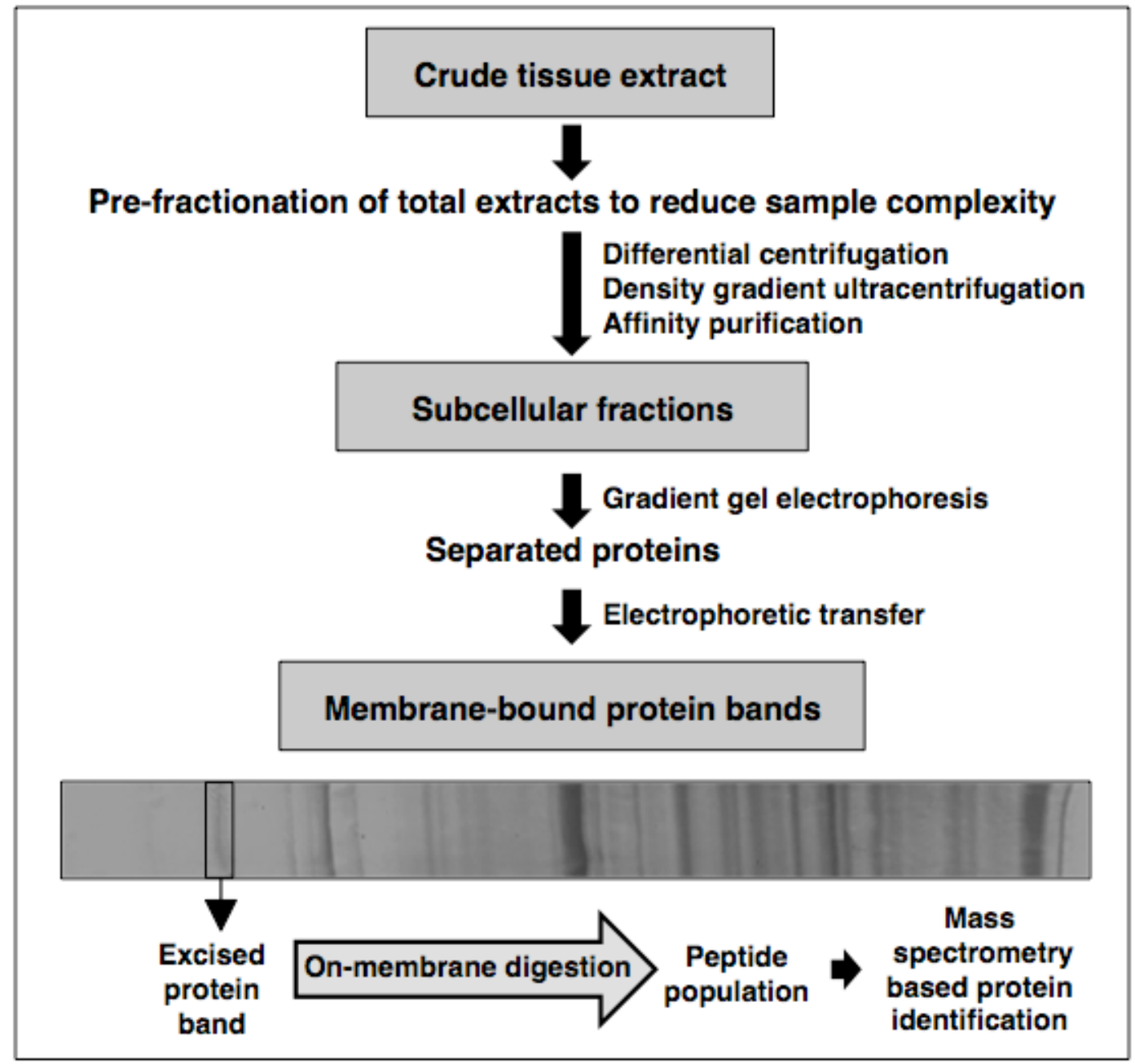

Figure 2: Flowchart of preparative steps employed in the subcellular fractionation of membrane-associated proteins for organelle proteomics. Listed are major biochemical techniques that are routinely used in pre-fractionation procedures to reduce sample complexity in the proteomic analysis of crude tissue extracts, including differential centrifugation, density gradient ultracentrifugation and affinity isolation methods. The protein cohort of a particular subcellular fraction can be further separated by one-dimensional gradient gel electrophoresis, or other suitable methods, and transferred to a membrane sheet for onmembrane digestion. The image in the lower part of the figure represents a nitrocellulose replica of gel electrophoretically separated sarcolemma vesicles from skeletal muscle, labeled with MemCode stain for visualization of individual protein bands. The marked band contains a high-molecular-mass protein that had previously not been identified by standard two-dimensional gel electrophoresis and in-gel digestion, but was clearly recognized as the Dp427 isoform of the membrane cytoskeletal protein dystrophin by on-membrane digestion and mass spectrometry.

identified dystrophin of $427 \mathrm{kDa}$ and its associated glycoprotein $\alpha$-syntrophin in the sarcolemma fraction following on-membrane digestion [97].

Sophisticated pre-fractionation steps were needed to study the isolated dystrophin complex by mass spectrometry. In one subproteomic approach sarcolemmal $\beta$-dystroglycan and tightly associated members of the dystrophin-glycoprotein complex were isolated by immuno precipitation from detergentsolubilized skeletal muscle and then identified by mass spectrometry [132]. In another proteomic study, the dystrophin-glycoprotein complex was purified to homogeneity, separated by gel electrophoresis and then peptides generated by on-membrane digestion for mass spectrometric analysis [97]. Following solubilization with the detergent digitonin, muscle membrane proteins were separated by a combination of ion exchange chromatography, lectin chromatography, sucrose gradient centrifugation and one-dimensional gradient gel electrophoresis. The mass spectrometric analysis of nitrocellulose replicas revealed the presence of dystrophin isoform Dp427 and its associated proteins $\alpha$-sarcoglycan, $\gamma$ sarcoglycan and dystrobrevin [97]. This confirmed the tight linkage between the membrane cytoskeletal protein dystrophin and integral proteins of the muscle plasmalemma by proteomics. 


\section{Gel electrophoretically separated Proteome}

\begin{tabular}{c|l} 
Transblotting & $\begin{array}{l}\text { Electrophoretic transfer buffer: } \\
25 \mathrm{mM} \text { Tris, } 192 \mathrm{mM} \text { glycine, } \mathrm{pH} \\
\text { at } 4^{\circ} \mathrm{C} \text { for } 70 \mathrm{~min} \text { at } 100 \mathrm{~V}\end{array}$ \\
$20 \%(\mathrm{v} / \mathrm{v})$ methanol
\end{tabular}

Membrane-based gel replica

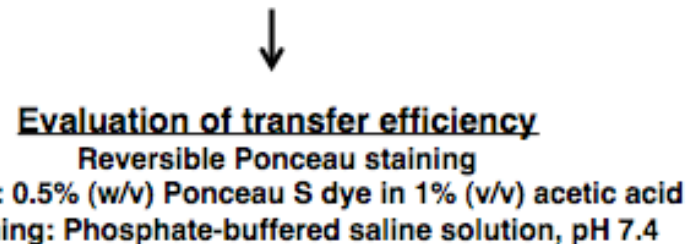

Destaining: Phosphate-buffered saline solution, $\mathrm{pH} 7.4$

\section{Digestion of immobilized protein bands or spots}

(i) Excision of protein bands from membrane sheets

(ii) Destaining of protein bands of interest and washing step

(iii) Blocking with $0.5 \%$ polyvinylpyrrolidone (PVP-40) at $37^{\circ} \mathrm{C}$

(iv) Washing with distilled water

(v) Overnight digestion of protein bands at $37^{\circ} \mathrm{C}$ in $100 \mu l$ trypsin solution $\rightarrow$ Trypsin stock solution: $20 \mu \mathrm{g}$ trypsin in $1.5 \mathrm{ml}$ of buffer 1:1 (v/v) $100 \mathrm{mM}$ ammonium bicarbonate/10\% acetonitrile

(vi) Extraction of trpysin-treated membranes with gentle agitation for 15 min at $37^{\circ} \mathrm{C}$ using $100 \mu \mathrm{l}$ extraction buffer

$\rightarrow$ Extraction buffer: 1:2 (v/v) $5 \%$ formic acid/acetonitrile

(vii) Collection of supernatant fractions with peptide mixtures

(viii) Transfer into fresh plastic tubes

(ix) Drying of peptides by vacuum centrifugation

(x) Reconstitution of peptides in LC running buffer $(0.1 \%$ formic acid)

(xi) Removal of contaminating membrane particles by centrifugation through $22 \mu \mathrm{m}$ cellulose spin filter tubes

(xii) Transfer of aliquots to LC-MS vials<smiles>C1CCCC1</smiles>

\section{Mass spectrometric identification of proteins}

Figure 3: Flowchart of the main preparative steps used in the on-membrane digestion of gel electrophoretically separated proteins. Listed are the experimental conditions and main buffers employed in transblotting from gels to membrane sheets, as well as the proteolytic generation of peptide populations for the mass spectrometric identification of individual protein species.

\section{RYANODINE RECEPTOR IDENTIFICATION BY ON-MEMBRANE DIGESTION}

In skeletal muscle fibres, excitation-contraction coupling is mediated by complex spatiotemporal interactions between several $\mathrm{Ca}^{2+}$-handling proteins [133]. The sarcoplasmic reticulum contains very high levels of $\mathrm{Ca}^{2+}$-ions and cycling of the second messenger molecule through the lumen of this organelle determines the contractile status of muscle fibres [134]. Following excitation of the sarcolemma above a critical physiological threshold level and subsequent propagation of an action potential along the transverse tubular membrane system, the $\alpha_{1 S^{-}}$ subunit of the dihydropyridine receptor acts as a voltage sensor and upon activation this protein complex interacts directly with ryanodine receptor $\mathrm{Ca}^{2+}$. release channels at the triad junction [135]. $\mathrm{Ca}^{2+}$-ions are buffered by the luminal ion-binding proteins calsequestrin and sarcalumenin, and the energydependent re-uptake of $\mathrm{Ca}^{2+}$-ions is achieved by the 
SERCA-type $\mathrm{Ca}^{2+}$-ATPases during fibre relaxation [133]. The ryanodine receptor $\mathrm{Ca}^{2+}$-release channel of the sarcoplasmic reticulum exists at the contact sites between the terminal cisternae and the transverse tubules as an integral tetramer with a molecular mass of over 2,000 kDa [119]. The gigantic size of the native ryanodine receptor complex makes it difficult to study this type of hydrophobic protein by conventional biochemical methodology. Routine two-dimensional gel electrophoresis can separate proteins from crude skeletal muscle extracts with a molecular mass not much greater than $200 \mathrm{kDa}$ [67-69]. In stark contrast, one-dimensional gels using $3-12 \%$ gradients can properly separate very large membrane proteins with molecular masses up to $2,000 \mathrm{kDa}[51,136]$.

This separating capacity of one-dimensional gradient gel electrophoresis for proteins of very high molecular mass was exploited in a recent onmembrane digestion-based characterization of the isolated sarcoplasmic reticulum [98]. Mass spectrometric analysis identified proteins in 31 distinct bands. This included the main $\mathrm{Ca}^{2+}$-regulatory proteins involved in excitation-contraction coupling, muscle relaxation and ion homeostasis, such as the RyR1 isoform of the junctional ryanodine receptor $\mathrm{Ca}^{2+}$ release channel of $565 \mathrm{kDa}$, the SERCA1 isoform of the $\mathrm{Ca}^{2+}$-ATPase of $110 \mathrm{kDa}$, the luminal $\mathrm{Ca}^{2+}$-shuttle protein sarcalumenin of $160 \mathrm{kDa}$, and the high-capacity $\mathrm{Ca}^{2+}$-buffering protein calsequestrin of $63 \mathrm{kDa}$ [98]. The position of these $\mathrm{Ca}^{2+}$-handling proteins in onedimensional gradient gels was confirmed by immunoblotting. Previous structural studies have indicated that glycolytic enzymes are present on the sarcoplasmic reticulum [137]. This was confirmed by on-membrane digestion of the purified sarcoplasmic reticulum, which demonstrated the presence of aldolase and phosphofructokinase in the purified membrane fraction [98]. These proteomic findings agree with the concept of close physical coupling between the energy-dependent sarcoplasmic reticulum and the ATP-producing glycolytic pathway [138].

\section{CONCLUSIONS}

Mass spectrometry-based proteomics is a powerful approach to catalogue entire protein populations present in body liquids, cells or tissues and is widely used to determine protein changes in biological systems in health and disease. Since current biochemical separation methods may under-estimate the presence of certain classes of proteins in whole tissue proteomics, organelle and membrane proteomics has been developed to fully cover the entire spectrum of proteins in a given tissue. This makes subproteomics an important part of modern protein biochemistry. In the case of large-scale protein separation approaches using two-dimensional gel electrophoresis, in-gel digestion is widely employed to produce peptides for subsequent mass spectrometric analysis. However, in some cases trypsination is inefficient for comprehensive in-gel digestion and alternative techniques with membrane replicas of gels have been shown to result in superior results. Onmembrane digestion of gel electrophoretically separated proteins is especially useful for the identification of proteins with a low abundance, high molecular mass, a considerable degree of hydrophobicity and/or extreme isoelectric points. The recent application of on-membrane digestion in skeletal muscle proteomics has resulted in the mass spectrometric identification of extremely large membrane-associated proteins, i.e. the Dp427 isoform of dystrophin and the RyR1 isoform of the ryanodine receptor $\mathrm{Ca}^{2+}$-release channel. These muscle proteins were previously not detected by routine proteomic surveys of various skeletal muscle tissues. This shows that mass spectrometry-based subproteomics can be successfully utilized for the identification and biochemical characterization of membrane-associated muscle proteins with a low density in muscle fibres. Large muscle proteins adsorbed onto nitrocellulose sheets seem to be more accessible to tryptic digestion, which increases the number of generated peptides for mass spectrometry. Hence, the usage of subcellular fractionation, in combination with gel electrophoresis and on-membrane digestion, can be extremely helpful for the future identification of protein species that are currently not fully recognized in proteomic studies of total cellular extracts.

\section{ACKNOWLEDGEMENTS}

The author would like to thank the Irish Higher Education Authority (PRTLI5) and Muscular Dystrophy Ireland for continued funding of our proteomics research in the Muscle Biology Laboratory, NUI Maynooth.

\section{REFERENCES}

[1] Hayes PC, Wolf $C R$, Hayes JD. Blotting techniques for the study of DNA, RNA, and proteins. BMJ 1989; 299: 965-8. http://dx.doi.org/10.1136/bmj.299.6705.965

[2] Southern EM. Detection of specific sequences among DNA fragments separated by gel electrophoresis. J Mol Biol 1975; 98: 503-17. http://dx.doi.org/10.1016/S0022-2836(75)80083-0 
[3] Alwine JC, Kemp DJ, Stark GR. Method for detection of specific RNAs in agarose gels by transfer to diazobenzyloxymethyl-paper and hybridization with DNA probes. Proc Natl Acad Sci USA 1977; 74: 5350-4. http://dx.doi.org/10.1073/pnas.74.12.5350

[4] Burnette WN. "Western blotting": electrophoretic transfer of proteins from sodium dodecyl sulfate-polyacrylamide gels to unmodified nitrocellulose and radiographic detection with antibody and radioiodinated protein A. Anal Biochem 1981; 112: 195-203.

http://dx.doi.org/10.1016/0003-2697(81)90281-5

[5] Kroczek RA. Southern and northern analysis. J Chromatogr 1993; 618: 133-45.

[6] Kurien BT, Scofield RH. Protein blotting: a review. J Immunol Methods 2003; 274: 1-15. http://dx.doi.org/10.1016/S0022-1759(02)00523-9

[7] Towbin H, Staehelin T, Gordon J. Electrophoretic transfer of proteins from polyacrylamide gels to nitrocellulose sheets: procedure and some applications. Proc Natl Acad Sci USA 1979; 76: 4350-4. http://dx.doi.org/10.1073/pnas.76.9.4350

[8] Ursitti JA, Mozdzanowski J, Speicher DW. Electroblotting from polyacrylamide gels. Curr Protoc Protein Sci 2001; Chapter 10: Unit 10.7.

[9] Kurien BT, Scofield RH. Western blotting. Methods 2006; 38 : 283-93.

http://dx.doi.org/10.1016/j.ymeth.2005.11.007

[10] Kurien BT, Scofield RH. A brief review of other notable protein blotting methods. Methods Mol Biol 2009; 536: 36784.

http://dx.doi.org/10.1007/978-1-59745-542-8 38

[11] MacPhee DJ. Methodological considerations for improving Western blot analysis. J Pharmacol Toxicol Methods 2010; 61: 171-7.

http://dx.doi.org/10.1016/j.vascn.2009.12.001

[12] Handen JS, Rosenberg HF. An improved method for Southwestern blotting. Front Biosci 1997; 2: c9-c11.

[13] Siu FK, Lee LT, Chow BK. Southwestern blotting in investigating transcriptional regulation. Nat Protoc 2008; 3: 51-8.

http://dx.doi.org/10.1038/nprot.2007.492

[14] Labbe S, Harrisson JF, Seguin C. Identification of sequencespecific DNA-binding proteins by southwestern blotting. Methods Mol Biol 2009; 543: 151-61. http://dx.doi.org/10.1007/978-1-60327-015-1 12

[15] Edmondson DG, Roth SY. Identification of protein interactions by far Western analysis. Curr Protoc Mol Biol 2001; Chapter 20: Unit 20.6.

[16] Chan CS, Winstone TM, Turner RJ. Investigating proteinprotein interactions by far-Westerns. Adv Biochem Eng Biotechnol 2008; 110: 195-14. http://dx.doi.org/10.1007/10 2007090

[17] Machida K, Mayer BJ. Detection of protein-protein interactions by far-western blotting. Methods Mol Biol 2009; 536: 313-29.

http://dx.doi.org/10.1007/978-1-59745-542-8 34

[18] Glover L, Froemming G, Ohlendieck K. Calsequestrin blot overlay of two-dimensional electrophoretically separated microsomal proteins from skeletal muscle. Anal Biochem 2001; 299: 268-71.

http://dx.doi.org/10.1006/abio.2001.5424

[19] Glover L, Quinn S, Ryan M, Pette D, Ohlendieck K. Supramolecular calsequestrin complex. Eur J Biochem 2002; 269: 4607-16.

http://dx.doi.org/10.1046/j.1432-1033.2002.03160.x

[20] Strom A, Diecke S, Hunsmann G, Stuke AW. Identification of prion protein binding proteins by combined use of farWestern immunoblotting, two dimensional gel electrophoresis and mass spectrometry. Proteomics 2006; 6: 26-34.

http://dx.doi.org/10.1002/pmic.200500066

[21] Ino $\mathrm{Y}$, Hirano $\mathrm{H}$. Mass spectrometric characterization of proteins transferred from polyacrylamide gels to membrane filters. FEBS J 2011; 278: 3807-14. http://dx.doi.org/10.1111/j.1742-4658.2011.08303.x

[22] Simspon RJ. On-membrane proteolytic digestion of electroblotted proteins. Cold Spring Harb Protoc 2011; 2011: 995-7.

[23] Han X, Aslanian A, Yates JR 3rd. Mass spectrometry for proteomics. Curr Opin Chem Biol 2008; 12: 483-90. http://dx.doi.org/10.1016/j.cbpa.2008.07.024

[24] Chait BT. Mass spectrometry in the postgenomic era. Annu Rev Biochem 2011; 80: 239-46. http://dx.doi.org/10.1146/annurev-biochem-110810-095744

[25] Angel TE, Aryal UK, Hengel SM, Baker ES, Kelly RT, Robinson EW, et al. Mass spectrometry-based proteomics: existing capabilities and future directions. Chem Soc Rev 2012; 41: 3912-28.

http://dx.doi.org/10.1039/c2cs15331a

[26] Walther TC, Mann M. Mass spectrometry-based proteomics in cell biology. J Cell Biol 2010; 190: 491-500.

http://dx.doi.org/10.1083/jcb.201004052

[27] Schirle M, Bantscheff M, Kuster B. Mass spectrometry-based proteomics in preclinical drug discovery. Chem Biol 2012; 19: 72-84.

http://dx.doi.org/10.1016/i.chembiol.2012.01.002

[28] Sabido E, Selevsek N, Aebersold R. Mass spectrometrybased proteomics for systems biology. Curr Opin Biotechnol 2012; 23: 591-7. http://dx.doi.org/10.1016/j.copbio.2011.11.014

[29] Xie F, Liu T, Qian WJ, Petyuk VA, Smith RD. Liquid chromatography-mass spectrometry-based quantitative proteomics. J Biol Chem 2011; 286: 25443-9.

http://dx.doi.org/10.1074/jbc.R110.199703

[30] Gauci VJ, Wright EP, Coorssen JR. Quantitative proteomics: assessing the spectrum of in-gel protein detection methods. J Chem Biol 2011; 4: 3-29.

http://dx.doi.org/10.1007/s12154-010-0043-5

[31] Yates JR 3rd, Gilchrist A, Howell KE, Bergeron JJ. Proteomics of organelles and large cellular structures. Nat Rev Mol Cell Biol 2005; 6: 702-14. http://dx.doi.org/10.1038/nrm1711

[32] Gauthier DJ, Lazure C. Complementary methods to assist subcellular fractionation in organellar proteomics. Expert Rev Proteomics 2008; 5: 603-17. http://dx.doi.org/10.1586/14789450.5.4.603

[33] Lee YH, Tan HT, Chung MC. Subcellular fractionation methods and strategies for proteomics. Proteomics 2010; 10 3935-56.

http://dx.doi.org/10.1002/pmic.201000289

[34] Shevchenko A, Tomas H, Havlis J, Olsen JV, Mann M. In-gel digestion for mass spectrometric characterization of proteins and proteomes. Nat Protoc 2006; 1: 2856-60.

http://dx.doi.org/10.1038/nprot.2006.468

[35] Granvogl B, Plöscher M, Eichacker LA. Sample preparation by in-gel digestion for mass spectrometry-based proteomics. Anal Bioanal Chem 2007; 389: 991-1002. http://dx.doi.org/10.1007/s00216-007-1451-4

[36] Righetti PG, Candiano G. Recent advances in electrophoretic techniques for the characterization of protein biomolecules: a poker of aces. J Chromatogr A 2011; 1218: 8727-37.

http://dx.doi.org/10.1016/j.chroma.2011.04.011

[37] Wittig I, Schagger H. Native electrophoretic techniques to identify protein-protein interactions. Proteomics 2009; 9: 5214-23.

http://dx.doi.org/10.1002/pmic.200900151 
[38] Righetti PG, Castagna A, Herbert B, Reymond F, Rossier JS. Prefractionation techniques in proteome analysis. Proteomics 2003; 3: 1397-407. http://dx.doi.org/10.1002/pmic.200300472

[39] Mulvey C, Ohlendieck K. Use of continuous-elution gel electrophoresis as a preparative tool for blot overlay analysis. Anal Biochem 2003; 319: 122-30.

http://dx.doi.org/10.1016/S0003-2697(03)00321-X

[40] Righetti PG, Castagna A, Antonioli P, Boschetti E. Prefractionation techniques in proteome analysis: the mining tools of the third millennium. Electrophoresis 2005; 26: 29719.

http://dx.doi.org/10.1002/elps.200406189

[41] Ros A, Faupel M, Mees H, Oostrum J, Ferrigno R, Reymond $\mathrm{F}$, et al. Protein purification by Off-Gel electrophoresis. Proteomics 2002; 2: 151-6.

http://dx.doi.org/10.1002/1615-9861(200202)2:2<151::AIDPROT151>3.0.CO;2-9

[42] Horth P, Miller CA, Preckel T, Wenz C. Efficient fractionation and improved protein identification by peptide OFFGEL electrophoresis. Mol Cell Proteomics 2006; 5: 1968-74. http://dx.doi.org/10.1074/mcp.T600037-MCP200

[43] Keidel EM, Dosch D, Brunner A, Kellermann J, Lottspeich F. Evaluation of protein loading techniques and improved separation in OFFGEL isoelectric focusing. Electrophoresis 2011; 32: 1659-66.

[44] Gannon J, Ohlendieck K. Subproteomic analysis of basic proteins in aged skeletal muscle following offgel prefractionation. Mol Med Report 2012; 5: 993-1000.

[45] Garfin DE. Two-dimensional gel electrophoresis: an overview. Trends Anal Chem 2003; 22: 263-72. http://dx.doi.org/10.1016/S0165-9936(03)00506-5

[46] Gorg A, Weiss W, Dunn MJ. Current two-dimensional electrophoresis technology for proteomics. Proteomics 2004; 4: $3665-85$ http://dx.doi.org/10.1002/pmic.200401031

[47] Wittmann-Liebold B, Graack HR, Pohl T. Two-dimensional gel electrophoresis as tool for proteomics studies in combination with protein identification by mass spectrometry. Proteomics 2006; 6: 4688-703. http://dx.doi.org/10.1002/pmic.200500874

[48] Rabilloud T, Chevallet M, Luche S, Lelong C. Twodimensional gel electrophoresis in proteomics: Past, present and future. J Proteomics 2010; 73: 2064-77. http://dx.doi.org/10.1016/j.jprot.2010.05.016

[49] Rabilloud T, Lelong C. Two-dimensional gel electrophoresis in proteomics: a tutorial. J Proteomics 2011; 74: 1829-41. http://dx.doi.org/10.1016/j.jprot.2011.05.040

[50] Wittig I, Schagger H. Features and applications of bluenative and clear-native electrophoresis. Proteomics 2008; 8: 3974-90.

http://dx.doi.org/10.1002/pmic.200800017

[51] Froemming GR, Murray BE, Ohlendieck K. Self-aggregation of triadin in the sarcoplasmic reticulum of rabbit skeletal muscle. Biochim Biophys Acta 1999; 1418: 197-205. http://dx.doi.org/10.1016/S0005-2736(99)00024-3

[52] Wu J, Lenchik NJ, Pabst MJ, Solomon SS, Shull J, Gerling IC. Functional characterization of two-dimensional gelseparated proteins using sequential staining. Electrophoresis 2005; 26: 225-37.

http://dx.doi.org/10.1002/elps.200406176

[53] Weiss W, Gorg A. High-resolution two-dimensional electrophoresis. Methods Mol Biol 2009; 564: 13-32. http://dx.doi.org/10.1007/978-1-60761-157-8 2

[54] Steinberg TH. Protein gel staining methods: an introduction and overview. Methods Enzymol 2009; 463: 541-63. http://dx.doi.org/10.1016/S0076-6879(09)63031-7
[55] Weiss W, Weiland F, Gorg A. Protein detection and quantitation technologies for gel-based proteome analysis. Methods Mol Biol 2009; 564: 59-82. http://dx.doi.org/10.1007/978-1-60761-157-8 4

[56] Brewis IA, Brennan P. Proteomics technologies for the global identification and quantification of proteins. Adv Protein Chem Struct Biol 2010; 80: 1-44.

http://dx.doi.org/10.1016/B978-0-12-381264-3.00001-1

[57] Rabilloud T. Silver staining of $2 \mathrm{D}$ electrophoresis gels. Methods Mol Biol 2012; 893: 61-73.

http://dx.doi.org/10.1007/978-1-61779-885-6 5

[58] Lopez MF, Berggren K, Chernokalskaya E, Lazarev A, Robinson M, Patton WF. A comparison of silver stain and SYPRO Ruby Protein Gel Stain with respect to protein detection in two-dimensional gels and identification by peptide mass profiling. Electrophoresis 2000; 21 : 3673-83. http://dx.doi.org/10.1002/15222683(200011)21:17<3673::AID-ELPS3673>3.0.CO;2-M

[59] Patton WF. A thousand points of light: the application of fluorescence detection technologies to two-dimensional gel electrophoresis and proteomics. Electrophoresis 2000; 21: 1123-44.

http://dx.doi.org/10.1002/(SICI)1522-

2683(20000401)21:6<1123::AID-ELPS1123>3.0.CO;2-E

[60] Westermeier R, Marouga R. Protein detection methods in proteomics research. Biosci Rep 2005; 25: 19-32.

http://dx.doi.org/10.1007/s10540-005-2845-1

[61] Aude-Garcia C, Collin-Faure V, Luche S, Rabilloud T. Improvements and simplifications in in-gel fluorescent detection of proteins using ruthenium II tris(bathophenanthroline disulfonate): the poor man's fluorescent detection method. Proteomics 2011; 11: 324-8. http://dx.doi.org/10.1002/pmic.201000370

[62] Minden JS, Dowd SR, Meyer HE, Stühler K. Difference gel electrophoresis. Electrophoresis 2009; 30(Suppl 1): S156-61. http://dx.doi.org/10.1002/elps.200900098

[63] Marouga R, David S, Hawkins E. The development of the DIGE system: 2D fluorescence difference gel analysis technology. Anal Bioanal Chem 2005; 382: 669-78. http://dx.doi.org/10.1007/s00216-005-3126-3

[64] Timms JF, Cramer R. Difference gel electrophoresis. Proteomics 2008; 8: 4886-97. http://dx.doi.org/10.1002/pmic.200800298

[65] Dautel F, Kalkhof S, Trump S, Lehmann I, Beyer A, von Bergen M. Large-scale 2-D DIGE studies - guidelines to overcome pitfalls and challenges along the experimental procedure. J Integr OMICS 2011; 1: 170-9.

[66] Alban A, David SO, Bjorkesten L, Andersson C, Sloge E, Lewis $S$, et al. A novel experimental design for comparative two-dimensional gel analysis: two-dimensional difference gel electrophoresis incorporating a pooled internal standard. Proteomics 2003; 3: 36-44.

http://dx.doi.org/10.1002/pmic.200390006

[67] Doran P, Martin G, Dowling P, Jockusch H, Ohlendieck K. Proteome analysis of the dystrophin-deficient MDX diaphragm reveals a drastic increase in the heat shock protein cvHSP. Proteomics 2006; 6(16): 4610-21.

http://dx.doi.org/10.1002/pmic.200600082

[68] Doran P, O'Connell K, Gannon J, Kavanagh M, Ohlendieck K. Opposite pathobiochemical fate of pyruvate kinase and adenylate kinase in aged rat skeletal muscle as revealed by proteomic DIGE analysis. Proteomics 2008; 8: 364-77. http://dx.doi.org/10.1002/pmic.200700475

[69] Lewis C, Doran P, Ohlendieck K. Proteomic analysis of dystrophic muscle. Methods Mol Biol 2012; 798: 357-69. http://dx.doi.org/10.1007/978-1-61779-343-1_20

[70] Beranova-Giorgianni S. Proteome analysis by twodimensional gel electrophoresis and mass spectrometry: 
strengths and limitations. Trends Anal Chem 2003; 22: 273281.

http://dx.doi.org/10.1016/S0165-9936(03)00508-9

[71] Tan S, Tan HT, Chung MC. Membrane proteins and membrane proteomics. Proteomics 2008; 8: 3924-32. http://dx.doi.org/10.1002/pmic.200800597

[72] Helbig AO, Heck AJ, Slijper M. Exploring the membrane proteome-challenges and analytical strategies. J Proteomics 2010; 73: 868-78.

http://dx.doi.org/10.1016/j.jprot.2010.01.005

[73] Groen AJ, Lilley KS. Proteomics of total membranes and subcellular membranes. Expert Rev Proteomics 2010; 7: 867-78.

http://dx.doi.org/10.1586/epr.10.85

[74] Mozdzanowski J, Speicher DW. Microsequence analysis of electroblotted proteins. I. Comparison of electroblotting recoveries using different types of PVDF membranes. Anal Biochem 1992; 207: 11-8. http://dx.doi.org/10.1016/0003-2697(92)90492-P

[75] Reim DF, Speicher DW. Microsequence analysis of electroblotted proteins. II. Comparison of sequence performance on different types of PVDF membranes. Anal Biochem 1992; 207: 19-23. http://dx.doi.org/10.1016/0003-2697(92)90493-Q

[76] Komatsu S. Western blotting/Edman sequencing using PVDF membrane. Methods Mol Biol 2009; 536: 163-71. http://dx.doi.org/10.1007/978-1-59745-542-8 18

[77] Baker CS, Dunn MJ. Preparation of proteins from gels for protein microsequencing. Methods Mol Biol 1994; 32: 17784.

[78] Sirawaraporn W. Preparation of blotted membrane for protein microsequencing. Methods Mol Biol 1993; 21: 431-40.

[79] Kurien BT, Scofield RH. Extraction of proteins from gels: a brief review. Methods Mol Biol 2012; 869: 403-5. http://dx.doi.org/10.1007/978-1-61779-821-4 33

[80] Aebersold RH, Leavitt J, Saavedra RA, Hood LE, Kent SB. Internal amino acid sequence analysis of proteins separated by one- or two-dimensional gel electrophoresis after in situ protease digestion on nitrocellulose. Proc Natl Acad Sci USA 1987; 84: 6970-4.

http://dx.doi.org/10.1073/pnas.84.20.6970

[81] Matsudaira P. Sequence from picomole quantities of proteins electroblotted onto polyvinylidene difluoride membranes. J Biol Chem 1987; 262: 10035-8.

[82] Hirano H, Komatsu S, Kajiwara H, Takagi Y, Tsunasawa S. Microsequence analysis of the $\mathrm{N}$-terminally blocked proteins immobilized on polyvinylidene difluoride membrane by western blotting. Electrophoresis 1993; 14: 839-46. http://dx.doi.org/10.1002/elps.11501401134

[83] Speicher KD, Kolbas O, Harper S, Speicher DW. Systematic analysis of peptide recoveries from in-gel digestions for protein identifications in proteome studies. J Biomol Tech 2000; 11: 74-86.

[84] Finehout EJ, Lee KH. Comparison of automated in-gel digest methods for femtomole level samples. Electrophoresis 2003; 24: 3508-16.

http://dx.doi.org/10.1002/elps.200305615

[85] Courchesne PL, Luethy R, Patterson SD. Comparison of ingel and on-membrane digestion methods at low to sub-pmol level for subsequent peptide and fragment-ion mass analysis using matrix-assisted laser-desorption/ionization mass spectrometry. Electrophoresis 1997; 18: 369-81. http://dx.doi.org/10.1002/elps.1150180311

[86] Schleuder D, Hillenkamp F, Strupat K. IR-MALDI-mass analysis of electroblotted proteins directly from the membrane: comparison of different membranes, application to on-membrane digestion, and protein identification by database searching. Anal Chem 1999; 71: 3238-47.

http://dx.doi.org/10.1021/ac9810720
[87] Methogo RM, Dufresne-Martin G, Leclerc P, Leduc R, Klarskov K. Mass spectrometric peptide fingerprinting of proteins after Western blotting on polyvinylidene fluoride and enhanced chemiluminescence detection. J Proteome Res 2005; 4: 2216-24. http://dx.doi.org/10.1021/pr050014+

[88] Nakanishi T, Ohtsu I, Furuta M, Ando E, Nishimura O. Direct MS/MS analysis of proteins blotted on membranes by a matrix-assisted laser desorption/ionization-quadrupole ion trap-time-of-flight tandem mass spectrometer. J Proteome Res 2005; 4: 743-7. http://dx.doi.org/10.1021/pr0497834

[89] Ohtsu I, Nakanisi T, Furuta M, Ando E, Nishimura O. Direct matrix-assisted laser desorption/ionization time-of-flight mass spectrometric identification of proteins on membrane detected by Western blotting and lectin blotting. J Proteome Res 2005; 4: 1391-6. http://dx.doi.org/10.1021/pr050073n

[90] Luque-Garcia JL, Zhou G, Sun TT, Neubert TA. Use of nitrocellulose membranes for protein characterization by matrix-assisted laser desorption/ionization mass spectrometry. Anal Chem 2006; 78: 5102-8.

http://dx.doi.org/10.1021/ac060344t

[91] Lin Y, Li Y, Liu Y, Han W, He Q, Li J, et al. Improvement of gel-separated protein identification by DMF-assisted digestion and peptide recovery after electroblotting. Electrophoresis 2009; 30: 3626-35. http://dx.doi.org/10.1002/elps.200900070

[92] Luque-Garcia JL, Neubert TA. On-membrane tryptic digestion of proteins for mass spectrometry analysis. Methods Mol Biol 2009; 536: 331-41.

http://dx.doi.org/10.1007/978-1-59745-542-8 35

[93] Strader MB, Tabb DL, Hervey WJ, Pan C, Hurst GB. Efficient and specific trypsin digestion of microgram to nanogram quantities of proteins in organic-aqueous solvent systems. Anal Chem 2006; 78: 125-34.

http://dx.doi.org/10.1021/ac051348I

[94] Wall MJ, Crowell AM, Simms GA, Carey GH, Liu F, Doucette AA. Implications of partial tryptic digestion in organicaqueous solvent systems for bottom-up proteome analysis. Anal Chim Acta 2011; 703:194-203.

http://dx.doi.org/10.1016/j.aca.2011.07.025

[95] Glatter T, Ludwig C, Ahrné E, Aebersold R, Heck AJ, Schmidt A. Large-scale quantitative assessment of different in-solution protein digestion protocols reveals superior cleavage efficiency of tandem Lys-C/trypsin proteolysis over trypsin digestion. J Proteome Res 2012; 11: 5145-56. http://dx.doi.org/10.1021/pr300273g

[96] Luque-Garcia JL, Zhou G, Spellman DS, Sun TT, Neubert TA. Analysis of electroblotted proteins by mass spectrometry: protein identification after Western blotting. Mol Cell Proteomics 2008; 7: 308-14.

http://dx.doi.org/10.1074/mcp.M700415-MCP200

[97] Lewis C, Ohlendieck K. Mass spectrometric identification of dystrophin isoform Dp427 by on-membrane digestion of sarcolemma from skeletal muscle. Anal Biochem 2010; 404: 197-203.

http://dx.doi.org/10.1016/j.ab.2010.05.017

[98] Staunton L, Ohlendieck K. Mass spectrometric characterization of the sarcoplasmic reticulum from rabbit skeletal muscle by on-membrane digestion. Protein Pept Lett 2012; 19: 252-63. http://dx.doi.org/10.2174/092986612799363208

[99] Steinberg TH, Pretty On Top K, Berggren KN, Kemper C Jones L, Diwu Z, et al. Rapid and simple single nanogram detection of glycoproteins in polyacrylamide gels and on electroblots. Proteomics 2001; 1: 841-55. http://dx.doi.org/10.1002/1615-9861(200107)1:7<841::AIDPROT841>3.0.CO;2-E 
[100] Hart C, Schulenberg B, Steinberg TH, Leung WY, Patton WF. Detection of glycoproteins in polyacrylamide gels and on electroblots using Pro-Q Emerald 488 dye, a fluorescent periodate Schiff-base stain. Electrophoresis 2003; 24: 58898. http://dx.doi.org/10.1002/elps.200390069

[101] Kimura S, Kameyama A, Nakaya S, Ito $H$, Narimatsu $H$. Direct on-membrane glycoproteomic approach using MALDITOF mass spectrometry coupled with microdispensing of multiple enzymes. J Proteome Res 2007; 6: 2488-94. http://dx.doi.org/10.1021/pr070067m

[102] Goodman T, Schulenberg B, Steinberg TH, Patton WF. Detection of phosphoproteins on electroblot membranes using a small-molecule organic fluorophore. Electrophoresis 2004; 25: 2533-8.

http://dx.doi.org/10.1002/elps.200406008

[103] Nakanishi T, Ando E, Furuta M, Tsunasawa S, Nishimura O. Direct on-membrane peptide mass fingerprinting with MALDIMS of tyrosine-phosphorylated proteins detected by immunostaining. J Chromatogr B Analyt Technol Biomed Life Sci 2007; 847: 24-9.

http://dx.doi.org/10.1016/j.jchromb.2006.08.024

[104] Bockus LB, Scofield RH. Phosphoprotein detection on protein electroblot using a phosphate-specific fluorophore. Methods Mol Biol 2009; 536: 385-93.

http://dx.doi.org/10.1007/978-1-59745-542-8 39

[105] Jiang D, Jia Y, Zhou Y, Jarrett HW. Two-dimensional southwestern blotting and characterization of transcription factors on-blot. J Proteome Res 2009; 8: 3693-701. http://dx.doi.org/10.1021/pr900214p

[106] Jiang D, Jia Y, Jarrett HW. Transcription factor proteomics: identification by a novel gel mobility shift-three-dimensional electrophoresis method coupled with southwestern blot and high-performance liquid chromatography-electrospray-mass spectrometry analysis. J Chromatogr A 2011; 1218: 7003-15. http://dx.doi.org/10.1016/j.chroma.2011.08.023

[107] Jarrett HW. Proteomic methodologies to study transcription factor function. Methods Mol Biol 2012; 786: 315-34. http://dx.doi.org/10.1007/978-1-61779-292-2 19

[108] Paulo JA, Kadiyala V, Banks PA, Steen H, Conwell DL. Mass spectrometry-based proteomics for translational research: a technical overview. Yale J Biol Med 2012; 85: 59-73.

[109] Terry DE, Umstot E, Desiderio DM. Optimized sampleprocessing time and peptide recovery for the mass spectrometric analysis of protein digests. J Am Soc Mass Spectrom 2004; 15: 784-94.

http://dx.doi.org/10.1016/j.jasms.2004.02.005

[110] Domon B, Aebersold R. Mass spectrometry and protein analysis. Science 2006; 312: 212-7.

http://dx.doi.org/10.1126/science.1124619

[111] Zhang G, Annan RS, Carr SA, Neubert TA. Overview of peptide and protein analysis by mass spectrometry. Curr Protoc Protein Sci 2010; Chapter 16: Unit16.1.

[112] Yates JR, Ruse Cl, Nakorchevsky A. Proteomics by mass spectrometry: approaches, advances, and applications. Annu Rev Biomed Eng 2009; 11: 49-79.

http://dx.doi.org/10.1146/annurev-bioeng-061008-124934

[113] Gundry RL, White MY, Murray Cl, Kane LA, Fu Q, Stanley $\mathrm{BA}$, et al. Preparation of proteins and peptides for mass spectrometry analysis in a bottom-up proteomics workflow. Curr Protoc Mol Biol 2009; Chapter 10: Unit10.25.

[114] Dave KA, Headlam MJ, Wallis TP, Gorman JJ. Preparation and analysis of proteins and peptides using MALDI TOF/TOF mass spectrometry. Curr Protoc Protein Sci 2011; Chapter 16: Unit 16.13.

[115] Ohlendieck K. Proteomics of skeletal muscle differentiation, neuromuscular disorders and fiber aging. Expert Rev Proteomics 2010; 7: 283-96.

http://dx.doi.org/10.1586/epr.10.2
[116] Gelfi C, Vasso M, Cerretelli P. Diversity of human skeletal muscle in health and disease: contribution of proteomics. $\mathrm{J}$ Proteomics 2011; 74: 774-95. http://dx.doi.org/10.1016/j.jprot.2011.02.028

[117] Ohlendieck K. Skeletal muscle proteomics: current approaches, technical challenges and emerging techniques. Skelet Muscle 2011; 1(1): 6 . http://dx.doi.org/10.1186/2044-5040-1-6

[118] Ohlendieck K. Towards an understanding of the dystrophinglycoprotein complex: linkage between the extracellular matrix and the membrane cytoskeleton in muscle fibers. Eur J Cell Biol 1996; 69: 1-10.

[119] Capes EM, Loaiza R, Valdivia HH. Ryanodine receptors. Skelet Muscle 2011; 1(1): 18. http://dx.doi.org/10.1186/2044-5040-1-18

[120] Broderick MJ, Winder SJ. Spectrin, alpha-actinin, and dystrophin. Adv Protein Chem 2005; 70: 203-46. http://dx.doi.org/10.1016/S0065-3233(05)70007-3

[121] Dalkilic I, Kunkel LM. Muscular dystrophies: genes to pathogenesis. Curr Opin Genet Dev 2003; 13: 231-8. http://dx.doi.org/10.1016/S0959-437X(03)00048-0

[122] Ohlendieck K, Ervasti JM, Snook JB, Campbell KP. Dystrophin-glycoprotein complex is highly enriched in isolated skeletal muscle sarcolemma. J Cell Biol 1991; 112: 135-48.

http://dx.doi.org/10.1083/jcb.112.1.135

[123] Ohlendieck K, Campbell KP. Dystrophin constitutes 5\% of membrane cytoskeleton in skeletal muscle. FEBS Lett 1991; 283: 230-4.

http://dx.doi.org/10.1016/0014-5793(91)80595-T

[124] Ohlendieck K, Campbell KP. Dystrophin-associated proteins are greatly reduced in skeletal muscle from mdx mice. J Cell Biol 1991; 115: 1685-94. http://dx.doi.org/10.1083/jcb.115.6.1685

[125] Ohlendieck K, Matsumura K, Ionasescu VV, Towbin JA, Bosch EP, Weinstein SL, et al. Duchenne muscular dystrophy: deficiency of dystrophin-associated proteins in the sarcolemma. Neurology 1993; 43(4): 795-800. http://dx.doi.org/10.1212/WNL.43.4.795

[126] Culligan KG, Mackey AJ, Finn DM, Maguire PB, Ohlendieck $\mathrm{K}$. Role of dystrophin isoforms and associated proteins in muscular dystrophy (review). Int J Mol Med 1998; 2: 639-48.

[127] Lewis C, Carberry S, Ohlendieck K. Proteomic profiling of $x-$ linked muscular dystrophy. J Muscle Res Cell Motil 2009; 30: 267-9.

http://dx.doi.org/10.1007/s10974-009-9197-6

[128] Ge Y, Molloy MP, Chamberlain JS, Andrews PC. Proteomic analysis of $\mathrm{mdx}$ skeletal muscle: Great reduction of adenylate kinase 1 expression and enzymatic activity. Proteomics 2003; 3: 1895-903. http://dx.doi.org/10.1002/pmic.200300561

[129] Doran P, Wilton SD, Fletcher S, Ohlendieck K. Proteomic profiling of antisense-induced exon skipping reveals reversal of pathobiochemical abnormalities in dystrophic $\mathrm{mdx}$ diaphragm. Proteomics 2009; 9: 671-85. http://dx.doi.org/10.1002/pmic.200800441

[130] Lewis C, Ohlendieck K. Proteomic profiling of naturally protected extraocular muscles from the dystrophin-deficient mdx mouse. Biochem Biophys Res Commun 2010; 396: 1024-9.

http://dx.doi.org/10.1016/j.bbrc.2010.05.052

[131] Ohlendieck K. Characterisation of the dystrophin-related protein utrophin in highly purified skeletal muscle sarcolemma vesicles. Biochim Biophys Acta 1996; 1283: 215-22.

http://dx.doi.org/10.1016/0005-2736(96)00102-2

[132] Yoon JH, Johnson E, Xu R, Martin LT, Martin PT, Montanaro F. Comparative Proteomic Profiling of DystroglycanAssociated Proteins in Wild Type, mdx, and Galgt2 
Transgenic Mouse Skeletal Muscle. J Proteome Res 2012; 11: 4413-24.

http://dx.doi.org/10.1021/pr300328r

[133] Murray BE, Froemming GR, Maguire PB, Ohlendieck K. Excitation-contraction-relaxation cycle: role of $\mathrm{Ca}^{2+}$-regulatory membrane proteins in normal, stimulated and pathological skeletal muscle (review). Int J Mol Med 1998; 1: 677-87.

[134] Rossi D, Barone V, Giacomello E, Cusimano V, Sorrentino V. The sarcoplasmic reticulum: an organized patchwork of specialized domains. Traffic 2008; 9: 1044-9. http://dx.doi.org/10.1111/j.1600-0854.2008.00717.x

[135] Leong $P$, MacLennan DH. Complex interactions between skeletal muscle ryanodine receptor and dihydropyridine receptor proteins. Biochem Cell Biol 1998; 76: 681-94. http://dx.doi.org/10.1139/098-079
[136] Murray BE, Ohlendieck K. Cross-linking analysis of the ryanodine receptor and alpha1-dihydropyridine receptor in rabbit skeletal muscle triads. Biochem J 1997; 324: 689-96.

[137] Xu KY, Becker LC. Ultrastructural localization of glycolytic enzymes on sarcoplasmic reticulum vesticles. J Histochem Cytochem 1998; 46: 419-27. http://dx.doi.org/10.1177/002215549804600401

[138] Ohlendieck K. Proteomics of skeletal muscle glycolysis. Biochim Biophys Acta 2010; 1804: 2089-101.

Received on 01-11-2012

Accepted on 25-01-2013

Published on 28-02-2013

DOI: http://dx.doi.org/10.6000/1929-6037.2013.02.01.1

(C) 2013 Kay Ohlendieck; Licensee Lifescience Global.

This is an open access article licensed under the terms of the Creative Commons Attribution Non-Commercial License (http://creativecommons.org/licenses/by-nc/3.0/) which permits unrestricted, non-commercial use, distribution and reproduction in any medium, provided the work is properly cited. 